\title{
SUPPORT FOR THE DEVELOPMENT OF TECHNICAL INFRASTRUCTURE BY RURAL DEVELOPMENT PROGRAM 2007-2013 IN RURAL AREAS IN POLAND
}

\author{
Agnieszka Wojewodzka-Wiewiorska ${ }^{1}, \mathrm{PhD}$ \\ ${ }^{1}$ Warsaw University of Life Sciences-SGGW
}

\begin{abstract}
The aim of the article is to determine how the Rural Development Program 2007-2013 supported the development of technical infrastructure in rural areas in Poland by implementing measure 321 . The size and structure of public funds spent by types of infrastructure was determined and regional diversification was indicated in this respect. On the example of water and sewage infrastructure, the amount of funds allocation was compared to the results achieved in the field of changes in technical infrastructure in rural areas at the local level. The conditions of abortion of funds are also presented. The following data sources were used: database of the Ministry of Agriculture and Rural Development, data of the Central Statistical Office and qualitative research. The largest allocation of funds concerned water supply and sewage infrastructure, followed by marketplaces and investments in renewable energy. There were No significant differences in the structure of the allocation of funds in the regions. The effects of support are visible at the local level; the rural areas are definitely dominating in the poviat's structure, characterized by a large increase in the percentage of population served by the water and sewage network in 2006-2015.
\end{abstract}

Key words: rural areas, technical infrastructure, services for the population, RDP 207-2013.

JEL code: $018, \mathrm{Q} 18$.

\section{Introduction}

Among the many problems of rural development in Poland, there is an underdevelopment of technical and social infrastructure and, consequently, problems in access to services by rural residents (Kondratowicz-Pozorska J., 2008; Heffner K, Klemens B., 2016). Both theory and practice combine the level of infrastructure equipment with the occurrence and intensity of the processes of socio-economic development (Bryden J, 2011). It is noted that infrastructure is a very important development factor (WojtasiewCz L. 1997, Parysek J., 2001). Development in areas where there is an infrastructure gap is very difficult, if possible and largely dependent on the presence of other strong factors (Galazka A., 2004). Rural areas in Poland are mostly characterized by low access to pro-development factors and a relatively low level of development in relation to other areas, especially cities. This is accompanied by underdevelopment of infrastructure, especially technical infrastructure (Klodzinski M., 2015). Particular difficulties in this regard occur in the smallest units. Lack of access to basic elements of technical and social infrastructure in rural areas affects the living conditions of residents (Manggat I., Zain R., Jamaluddin Z., 2018) and is the foundation of economic activity, determining its structure, scope and spatial location (Satish P., 2007; Rutkowska G. 2007; Wojewodzka A. 2010; Zekic S., Kleut Z., Matkovski B., 2017).

In recent years, in Poland, a lot has changed in terms of quantitative and qualitative changes regarding infrastructure devices, mainly due to the possibility of obtaining non-returnable support for the implementation of rural infrastructure projects as part of the cohesion policy and the common agricultural policy of the European Union. Potential beneficiaries of financial support offered under EU financial instruments are very often local self-governments (LAU 2), which in their tasks have the obligation to provide residents with access to technical and social infrastructure (Ustawa o samorzadzie gminnym, 1990). In practice, their activity in applying for funds varies (Rakowska J., 2016), depending on many factors, i.e. knowledge about support, the ability to prepare relevant

\footnotetext{
${ }^{1}$ Corresponding author. Tel.: +48 225934 076; fax: +48 225934 077; e-mail address: agnieszka_wojewodzka@sggw.pl
} 
documents, and financial capabilities of the unit related to providing own contribution (Stawicki M., Wojewodzka A, Zajac J., 2009).

The subject of the study is the Rural Development Program 2007-2013 (RDP 2007-2013) and its importance in the development of technical infrastructure in the rural area. The analysis covered measure 321 "Basic services for the economy and rural population" under axis III, which was entirely devoted to the support of technical infrastructure. The implementation of the measure complements the scope of support including investments planned for financing in 2007-2013 under cohesion policy, especially in programs such as regional operational programs, the Development of Eastern Poland program and the Infrastructure and Environment Program. Beneficiaries of measure 321 could be municipal self-governments or, in the case of marketplaces, inter-municipal associations. In the RDP 2007-2013, rural areas include rural, urban-rural communes and cities with less than 5,000 inhabitants. As part of the measure 321, the beneficiaries could apply for financial support for projects concerning: 1) water supply and wastewater management, in particular: a) water supply; b) wastewater disposal and treatment, including network sewage systems or farmstead sewage systems; 2) establishment of municipal waste collection, segregation and disposal system; 3) production or distribution of renewable energy, including energy from wind, water, geothermal energy, sun, biogas or biomass; 4) construction of broadband internet infrastructure; 5) construction or modernization of marketplaces (RDP 2007-2013, 2007). While discussing the issue of technical infrastructure support, it should be mentioned that municipalities could also apply for co-financing of this type of investment under the Leader approach (axis IV) of the RDP 2007-2013(WojewodzkaWiewiorska A., 2017), which will not be the subject of this study.

The aim of the paper was to present how the Rural Development Program 2007-2013 supported the development of technical infrastructure in rural areas in Poland by implementing measure 321 . To reach the purpose, the following tasks have been set: 1 ) to determine the size and structure of public funds spent by the type of supported infrastructure that could be co-financed; 2) to show the regional differentiation of the allocation of public funds; 3 ) to compare the amount of funds allocation with the obtained effects in the field of changes in technical infrastructure in the countryside at the local level 4) to identify of conditions for implementing measure 321 from the point of view of beneficiaries and implementing institutions.

The data was made available for the purposes of the study by the Ministry of Agriculture and Rural Development as at 31 Dec 2015 (MARD, 2017), in the form of a detailed database covering all projects implemented under measure 321. Taking into account the titles of projects, they were divided into categories depending on the type of infrastructure supported. The amount of the funds spent means the total public payments made in absolute terms according to the provisions of agreements of all beneficiaries. The paper used also the data from the Central Statistical Office. In the comparative analysis of the allocation of funds in regions, an indicator of expenditures per 1 inhabitant of rural areas was used, according to data for the Central Statistical Office of 2015 (CSO 2019). To determine the conditions for the implementation of public funds, data from individual indepth interviews conducted in 2016 were used. Interviews were carried out with the authorities of rural communes, which were beneficiaries of funds under measure 321 (IDI, $n=2$ ) and representatives of implementing institutions (IDI, $n=2$ ). In addition, the source of information was the programming documents of the Ministry of Agriculture and Rural Development in Poland for the years 2007-2013 and 2014-2020. The research process used appropriate qualitative and quantitative 
research methods: monographic method, content analysis and synthesis, grouping information and data using basic descriptive statistics such as arithmetic mean, median, quantiles.

\section{Research results and discussion}

\section{The size and directions of spending financial resources}

In Poland, PLN 773.4 million was spent on measure 321 from public funds, which constituted $10.5 \%$ of RDP 2007-2013 funds in total. As far as the directions of spending are concerned, projects aimed at the development of water and sewage infrastructure were definitely dominant (tab. 1). At the national level, $92.27 \%$ of the total funds of the entire operation were spent on them, implementing $82 \%$ of all projects. Another type of infrastructure in rural areas which has been subsidized is infrastructure connected with local trade. Marketplaces were built or modernized, and expenditures for this purpose accounted for $3.53 \%$ in the structure of expenditure of the entire measure. Projects on renewable sources received public support in the amount of 173.21 million PLN. In the structure of expenditures by directions, the share of projects covering the construction or purchase of infrastructure related to the operation of municipal waste management was small and represented $1.72 \%$ of the total. The participation of projects supporting the development of the Internet network can be regarded as marginal. The projects differed from each other with the size of the co-financing obtained, also within a given type of infrastructure, as evidenced by basic statistical measures. The largest co-financing on average came from projects concerning the development of water and sewage infrastructure and marketplaces.

Table 1

Projects implemented under measure 321 of RDP 2007-2013 in Poland

\begin{tabular}{|l|c|c|c|c|c|c|}
\hline \multirow{2}{*}{ Type of infrastructure } & \multirow{2}{*}{$\begin{array}{c}\text { Expenses } \\
\text { (PLN } \\
\text { million) }\end{array}$} & \multirow{2}{*}{$\begin{array}{c}\text { Expenses } \\
(\boldsymbol{\%})\end{array}$} & $\begin{array}{c}\text { Number } \\
\text { of } \\
\text { projects }\end{array}$ & \multicolumn{3}{|c|}{$\begin{array}{c}\text { Co-financing of the project } \\
\text { thousand PLN }\end{array}$} \\
\cline { 5 - 7 } & & & & average & minimum & maximum \\
\hline water supply and & 7135.56 & 92.27 & 4409 & 1618.41 & 11.9 & 10525.61 \\
\hline markets & 273.3 & 3.53 & 247 & 1106.46 & 41.78 & 4381.79 \\
\hline renewable energy & 173.21 & 2.24 & 274 & 632.16 & 23.11 & 3837.4 \\
\hline waste & 132.94 & 1.72 & 384 & 346.2 & 5.68 & 8233.3 \\
\hline Internet & 9.84 & 0.13 & 13 & 756.82 & 24.84 & 4013.95 \\
\hline other* & 6.24 & 0.08 & 6 & 1432.91 & 75.48 & 3859.32 \\
\hline measure 321 & 7733.4 & 100 & 5333 & 1450.11 & 5.68 & 10525.61 \\
\hline
\end{tabular}

* the title of the project does not allow assigning a project to one of the groups

Source: author's calculations based on MARD 2017 data

Analysing the structure of expenditures by type in the cross-section of regions, it can be concluded that individual regions did not differ in the directions of spending funds. In all voivodships, as in the whole country, the support of water supply and sewage infrastructure was dominant, which may result from existing needs in this area or be associated with high cost-consuming investments of this type, which without public funding could not be implemented by local governments based on own resources. Expenditure on water and sewage infrastructure constituted the smallest share in relation to the entire measure 321 in the Zachodniopomorskie Voivodeship (86.4\%), and the largest in the Opolskie and Wielkopolskie Voivodships (96\%). In absolute terms, the smallest allocation of funds took place in the Lubuskie and Opole voivodships (fig. 1), PLN 246 and PLN 250 million, respectively. They are relatively the smallest regions in Poland, which may be important in the implementation of this type of investment. In turn, the highest amount of funds in absolute terms was spent in Mazowieckie (PLN 883 million), Wielkopolskie (PLN 686 million) and Malopolskie (PLN 579 million), 
i.e. regions with relatively high development level as well as in the Lubelskie Voivodeship (PLN 551 million).

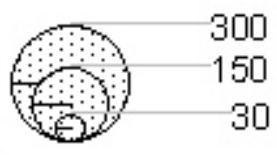

million PLN

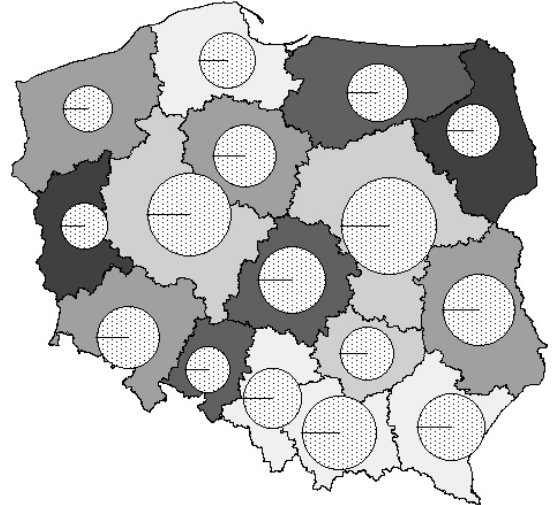

million PLN per capita

$647-724$

$516-647$

$478-516$

$437-478$

$333-437$

Source: author's calculations based on MARD 2017 data

Fig. 1. Regional variation in the size of public expenditure on the development of water and sewage infrastructure in Poland under measure 321 of RDP 2007-2013

With reference to the allocation of resources to the number of inhabitants of rural areas in individual regions, it can be stated that the largest amount of funds was spent in the Podlasie and Lubuskie voivodship (PLN 724 and 690 per capita). These are voivodships belonging to the so-called eastern walls (similarly to the Warminsko-Mazurskie Voivodeship, where the allocation was also high), characterized by a lower level of development in relation to the rest of the country. This may prove that the funds have been heavily used for neglected infrastructure. The least per capita funds - less than PLN 400 were spent in southern Poland, i.e. in the Slaskie, Malopolskie and Podkarpackie voivodships as well as in the Pomorskie voivodship (PLN 428).
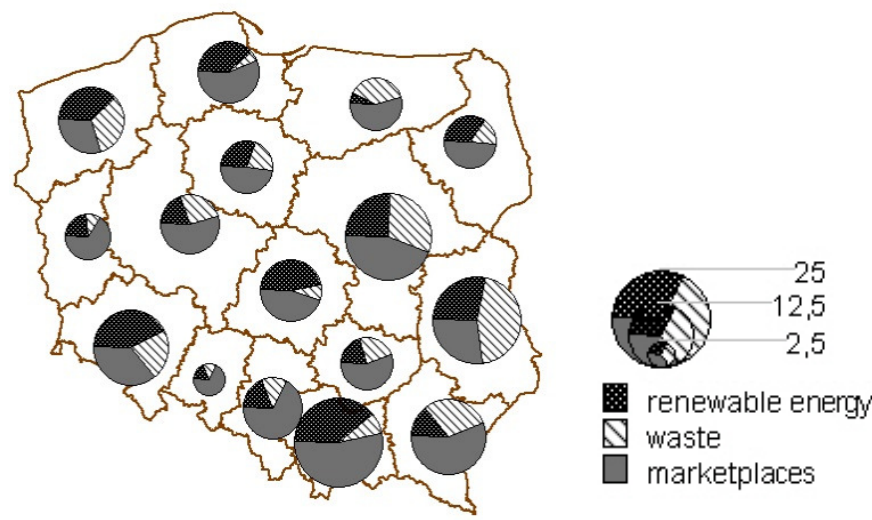

Source: author's calculations based on MARD 2017 data

Fig. 2. Regional variation in the amount of spending on infrastructure development in Poland as part of 321 RDP (PLN million)

Less funds were spent on infrastructural projects concerning other issues, i.e. waste, renewals of energy sources or construction of marketplaces, while at the same time they enjoyed less interest from beneficiaries. In the expenditure structure of measure 321 they constituted from 4 \% (Opolskie Voivodeship) to $13 \%$ (Zachodniopomorskie Voivodeship). Expenses for the construction and modernization of marketplaces dominated in 9 regions (fig. 2), which may result from the direct motivation of self-governments by the very fact of the possibility of obtaining financial support for this purpose under the RDP or from real needs in this area. Local governments have previously treated trade infrastructure not with the most urgent needs, especially since its modernization is expensive. In the Lodzkie, Dolnoslaskie, Malopolskie, Pomorskie and Zachodniopomorskie voivodeships there was a great interest in renewable energy sources, by far the smallest in the 
Warminsko-Mazurskie Voivodeship. These investments were treated as innovative and whether they were implemented or not depended on the knowledge and approach of local authorities and office staff. In individual voivodeship, there was a different interest in investments related to waste management, the largest in the municipalities of the Lubelskie and Warminsko-Mazurskie Voivodships. Internet projects were implemented only in 9 out of 16 provinces in Poland. In explaining this situation, it is necessary to take into account the fact that activities related to the Internet and renewable energy sources were introduced into the Common Agricultural Policy a bit later, due to the diagnosed needs and the adoption in 2008 of the European Economic Recovery Plan (Ledzion B., et al., 2016). After introducing these changes, it turned out that the interest of the beneficiaries in the development of the Internet is small. This resulted in the transfer of financial resources by reducing funds allocated for investments in the Internet, and increasing them to renewable energy sources, which were very popular.

\section{Typology of rural areas by poviats depending on the amount of funds obtained and the results achieved}

Considering the fact that the largest amount of public funds was directed to the development of water and sewage infrastructure and the availability of statistical data, the effects of the funds spent under measure 321 are shown on the example of this type of infrastructure. For the purpose of the study, the poviats in Poland ${ }^{1}$ were divided into types depending on: (1) the amount of absorption of funds under Measure 321 ( $A$ ) for water and sewage investments in rural areas (quartiles were used and the set was divided into poviats with relatively low absorption $\left(A \leq Q_{1}\right)$, average $\left(Q_{1}<A<Q_{3}\right)$ abd high $\left(A \geq Q_{3}\right)$ and $(2)$ changes in the percentage of population using the water supply and sewage network in 2006-2015 in rural areas (the median was used for percentage points and the set of poviats was divided into poviats characterized by low and high changes related to the population served by the networks). Thus, 12 types of rural areas were distinguished in the cross-section of poviats (tab. 2). In the structure of rural areas at the level of poviats, the dominance of three types of poviats can be found: type $F$ (average absorption of public funds giving effects in the form of the development of the water supply network), then type $\mathrm{H}$ (poviats with average absorption of funds and effects in the growth of population using the sewage network) and type G (poviats with average absorption, where there was a visible increase in the number of people using both types of networks). Among poviats there are units, where the absorption of RDP resources is low, and the effects in the form of network development are above average, which certainly results from supplementing this source of support with other external means, e.g. under the cohesion policy. This applies, among others Mazowieckie, Wielkopolskie and Dolnoslaskie voivodships, which, as highly developed areas, are cheap to implement many projects simultaneously, without fear of overburdening their budgets with the necessity to provide their own contribution. Interestingly, in the Podlasie voivodship as much as $25 \%$ of poviats is characterized by high absorption of funds, which is not accompanied by dynamic changes in the percentage of population using the network, and in every fifth poviat there is stagnation in infrastructure development with medium absorption of funds. The presented research results show that in Poland one can distinguish regions in which the greatest effects are visible in the case of the development of the water supply network. It can be a consequence of two issues. First of all, there are areas in Poland that are neglected in this respect (poorer), including those where 
the construction of the water supply is difficult for the municipality from an economic point of view (colonial housing).

Rural areas in Poland according to the amount of support from the RDP 20072013 activity and effects in the field of water and sewage infrastructure

\begin{tabular}{|c|c|c|c|c|c|c|}
\hline \multirow{2}{*}{$\begin{array}{l}\text { Type } \\
\text { of } \\
\text { rural } \\
\text { areas }\end{array}$} & \multicolumn{2}{|c|}{ Characteristics of areas } & \multirow{2}{*}{$\begin{array}{c}\text { Number } \\
\text { of } \\
\text { poviats }\end{array}$} & \multirow[t]{2}{*}{$\%$} & \multicolumn{2}{|c|}{$\begin{array}{l}\text { The voivodeship with } \\
\text { the largest share of the } \\
\text { type }\end{array}$} \\
\hline & Allocation & Type of effects & & & name & $\%$ \\
\hline A & low & stagnation & 29 & 9.24 & Podkarpacke & 20.7 \\
\hline B & low & water supply & 18 & 5.73 & Mazowieckie & 27.8 \\
\hline C & low & water supply, sewage system & 13 & 4.14 & Wielkopolskie & 23.1 \\
\hline D & low & sewage system & 19 & 6.05 & Dolnoslaskie & 21.1 \\
\hline $\mathbf{E}$ & average & stagnation & 31 & 9.87 & $\begin{array}{l}\text { Podlaskie, } \\
\text { Zachodniopomo } \\
\text { rskie }\end{array}$ & 19.4 \\
\hline $\mathbf{F}$ & average & water supply & 47 & 14.98 & Lubelskie & 19.1 \\
\hline G & average & water supply, sewage system & 36 & 11.46 & $\begin{array}{l}\text { Warminsko- } \\
\text { mazurskie }\end{array}$ & 16.7 \\
\hline $\mathbf{H}$ & average & sewage system & 42 & 13.38 & Wielkopolskie & 28.6 \\
\hline $\mathbf{I}$ & high & stagnation & 12 & 3.82 & Podlaskie & 25 \\
\hline $\mathbf{J}$ & high & water supply & 19 & 6.05 & Mazowieckie & 45 \\
\hline $\mathbf{K}$ & high & water supply, sewage system & 24 & 7.64 & Malopolskie & 20.8 \\
\hline $\mathbf{L}$ & high & sewage system & 24 & 7.64 & Podkarpackie & 29.2 \\
\hline
\end{tabular}

Source: author's calculations

On the other hand, some rural areas, located especially near large cities, are currently experiencing intensive development through a very dynamic increase in the number of new residents (mainly as a result of migration) and are forced to adapt their infrastructure to new realities. An important issue is also the large amount of diversity of Polish regions in the level of development (OECD, 2008), where in one region there are very well developed areas, including infrastructural ones and those characterized by infrastructure underdevelopment. Detailed conclusions in this respect could give more detailed research at the municipal level.

\section{Conditions for the implementation of projects in the field of technical infrastructure}

The two municipalities surveyed from the Podlasie Voivodship were characterized by deficiencies in the water and sewage infrastructure. and implemented respectively 3 and 2 projects from measure 321. According to the respondents co-financing from the RDP allowed to make up the existing arrears in the field of technical infrastructure, to improve the attractiveness of the area for residents and tourists. Among the barriers to applying for funds, first of all, there was No possibility to support road infrastructure, which could / should be built together with water and sewage infrastructure, lack of own funds for investments (especially for small municipalities); simultaneous need to modernize other elements of social infrastructure (mainly schools), which involves large financial resources and limits the possibility of implementing projects related to technical infrastructure. It was pointed out that support for RDP is very important for municipalities, also due to the ease of application and service in comparison with other support instruments. Without the RDP funds, water and sewage investments would be implemented because they are important from the point of view of the quality of life of the inhabitants, but would be significantly postponed („instead of 4 years would have been done in 15 years"). The respondents indicated that they intend to carry out projects related to the 
development of technical infrastructure with co-financing from RDP, which is also interesting for those related to renewable energy.

Research on the representatives of implementing institutions shows that the municipalities affected by investments with RDP co-financing are known to them, which was reflected in the provisions of RDP 2014-2020. PROW 2014-2020 supports basic services in the countryside in the following areas: (1) construction or modernization of local roads, (2) water and sewage management, and (3) development of marketplaces or construction facilities for the purpose of promoting local products. Thus, the beneficiaries' demand regarding the possibility of road support was taken into account, which in practice met with great interest from local governments. From the point of view of the implementing institutions, municipalities are good at absorbing funds for the development of technical infrastructure, which is most often seen locally, usually RDP funds constitute a major contribution to the municipal budget. The problem that sometimes occurs concerns, for example, connecting residents to new networks, who have the option of connecting, refusing to explain economic reasons. The respondents drew attention to a significant problem related to the current refund system. Municipalities (usually poorer) to indemnify their own contribution are excessively indebted, which often results in the loss of their creditworthiness. This situation excludes municipalities to which RDP support is addressed. In the opinion of the surveyed representatives of implementing institutions, the state of water supply and sewage infrastructure improved the most among all types of technical infrastructure. The most difficult was support for the development of the Internet, which resulted from the late appearance of funding opportunities for this type of investment and the practical difficulties in implementation and ignorance of potential beneficiaries.

\section{Conclusions, proposals, recommendations}

1) The RDP 2007-2013 in Poland enabled the development of technical infrastructure in the rural area through measure 321, to which PLN 773.4 million was directed, i.e. $10 \%$ of the funds of the entire Program. The largest allocation of funds concerned water supply and sewage infrastructure, followed by marketplaces and investments in renewable energy. There were No significant differences in the structure of the allocation of funds in the regions. This use of resources reflects the real needs of rural areas, which for various reasons have a need to build or modernize water and sewage infrastructure. Often, without external support, the municipalities would not be able to undertake these very expensive investments. It can be assumed that in the future the directions of infrastructural investments may change. Firstly, the important direction of the investment will be the modernization of local roads, to which, according to the expectations of potential beneficiaries, support from the RDP 2014-2020 can be obtained. In addition, after satisfying the needs of the water supply and sewage network, recognized as the basic element shaping the living conditions of the residents, the attention of beneficiaries will probably be directed to activities related to, for example, renewable energy sources treated in the examined perspective as innovative investments. This is also due to the change in the awareness of the authorities and residents and knowledge about the benefits, especially the economic benefits of using this type of energy.

2) The effects of support for infrastructure investments by RDP 2007-2013 are visible at the local level. In Poland, the poviat's structure is definitely dominated by rural areas characterized by a large increase in the percentage of population served by the water and sewage network in 20062015. 
3) Experience from the implementation of infrastructure projects 2007-2013 shows that for the allocation of funds to take place effectively, support should be prepared very well. Any changes during the term of the documents introduce chaos and result in low interest on the part of the beneficiaries and inefficient spending of funds, which is confirmed by the example of investment in the development of the Internet network.

\section{Bibliography}

1. Bryden, J. (2011). Rural Development Indicators and Diversity in the European Union. Retrieved: http://citeseerx.ist.psu.edu, p. 11. Access: 20.01.2019.

2. Central Statistical Office, Local Data Base. Retrieved: http://http://stat.gov.pl/bdl/. Access: 21.01.2019.

3. Galazka, A. (2004). Uwarunkowania i stan rozwoju infrastruktury na obszarach wiejskich w okresie transformacji (Conditions and State of Development of Infrastructure in the Rural Regions during the Transformation Period). Studia Obszarow Wiejskich. Vol 6. pp. 145-164.

4. Heffner, K., Klemens, B. (2016), Potencjaly i strefy problemowe w zakresie świadczenia uslug publicznych na obszarach wiejskich w skali regionalnej (Potentials and Problem Areas in the Provision of Public Services in Rural Areas at Regional Scale), Studia Obszarow Wiejskich, vol 42, pp. 26-28, doi.org/10.7163/SOW.42.2

5. Klodzinski, M., (2015). Zagrozenia i szanse stojace przed rozwojem sektora przedsiebiorczosci wiejskiej (Threats and Opportunities Facing the Developmental sector of Rural Entrepreneurship). Wies $i$ Rolnictwo. No 2. (167) pp. 125-138.

6. Kondratowicz-Pozorska, J. (2008). Analiza kierunkow rozwoju uslug na terenach wiejskich wojewodztwa zachodniopomorskiego w latach 2000-2006 (Analysis of Directions of Services Development in Rural Areas of West Pomeranian Region in Years 2000-2006). Zeszyty Naukowe SGGW - Ekonomika i Organizacja Gospodarki Zywnosciowej. No. 68. pp. 117-126.

7. Ledzion, B., Grabowska, I., Kupiec, T., Ploszaj, A., Widla-Domaradzki, L., Wojewodzka-Wiewiorska, A., Rauzer A. Wojtowicz, D. (2016). Ocena wplywu PROW 2007-2013 na jakosc zycia na obszarach wiejskich z uwzglednieniem podejscia LEADER (Evaluation of the RDP 2007-2013 Impact on Guality of Life in Rural Areas Taking into Account the LEADER Approach), Evaluation report, EGO, Warsaw, pp. 58-59; 115-116.

8. Manggat, I., Zain, R., Jamaluddin, Z., (2018). The Impact of Infrastructure Development on Rural Communities: A Literature Review, International Journal of Academic Research in Business and Social Sciences, 8(1), pp. 650-651.

9. Ministry of Agriculture and Rural Development. (2017). Data of the Agency for Restructuring and Modernization of Agriculture concerning the implementation of projects under the 3rd axis of the Rural Development Programme 2007-2013 from 31. Dec 2015.

10. Parysek, J. J. (2001). Podstawy gospodarki lokalnej (Basics of the Local Economy), Wydawnictwo Naukowe Uniwersytetu w Poznaniu, Poznan, p. 19.

11. Przeglady terytorialne OECD. Polska. (OECD Territorial Reviews Poland). (2008). Warsaw: OECD, p. 14.

12. Rakowska, J. (2016). Samorzady gmin jako beneficjenci polityki spojnosci UE w latach 2007-2013 (2015) (Municipal Self-governments as Beneficiaries of the EU's Policy of Cohesion in 2007-2013 (2015)). Wydawnictwo SGGW, Warszawa, pp. 92-94.

13. Rural Development Programme for 2007-2013. (2007). Ministry of Agriculture and Rural Development. Warsaw.

14. Rutkowska, G. (2007). Analiza porownawcza infrastruktury technicznej i spolecznej w wybranek gminie z wymogami UE (Comparative Analysis of Technical and Social Infrastructure in a Selected Commune with EU Requirements), Inzynieria i ksztaltowanie srodowiska, No 2(36), pp. 64-72.

15. Satish, P. (2007). Rural Infrastructure and Growth: An Overview. Indian Journal of Agricultural Economics. Vol. 62, No.1, Jan.-March. pp. 33-35.

16. Stawicki, M., Wojewodzka, A., Zajac, J. (2009). Uwarunkowania absorpcji funduszy strukturalnych UE na poziomie powiatow. Analiza i rekomendacje (Conditions of Absorption of EU Structural Funds at the Poviat Level. Analysis and Recommendations). Ministerstwo Rozwoju Regionalnego. Warsaw. pp. 31-33.

17. Ustawa o samorzadzie gminnym z dnia 8 marca 1990 r. (The Act of 8 March 1990 on Local Government), Dz.U. 1990 nr 16 poz. 95.

18. Wojewodzka, A. (2010). Infrastruktura jako czynnik rozwoju lokalnego i regionalnego (Infrastructure as a Factor of Local and Regional Development). Logistyka 2010; 3, pp. 1-13.

19. Wojewodzka-Wiewiorska, A. (2017). The Importance of the Leader Programme $2007-2013$ in the Rural Areas Development in Poland, Research for Rural Development Vol. 2, Jelgava, pp. 97-103. DOI: $10.22616 /$ rrd.23.2017.055.

20. Wojtasiewicz, L., Czynniki rozwoju lokalnego - nowe ujecia metodologiczne (Local Development Factors New Methodological Approaches), (in): Maik W., (ed.) Problematyka rozwoju lokalnego w warunkach transformacji systemowej, Biuletyn KPZK PAN, vol. 177, Warsaw, p. 10.

21.Zekic, S., Kleut, Z., Matkovski, B. (2017). An Analysis of Key Indicators of Rural Development in Serbia: a Comparison with EU Countries. Economic Annals, Volume LXII, No. 214 / July - September 2017, p. 118. 